\title{
ASSESSMENT OF POTENTIAL IMPACTS OF CLIMATE AND SOCIO-ECONOMIC CHANGES ON FUTURE WATER SECURITY IN THE HIMALAYAS, INDIA
}

\author{
Quan V. DAU ${ }^{1}$ (D), Kittiwet KUNTIYAWICHAI ${ }^{2 *}$ (D)
}

DOI: 10.21163/GT_2021.162.01

\begin{abstract}
:
The shifts in socio-economic development and climate conditions currently become the challenge for water resources system security in the Himalayan region. The aforesaid concern was found pertinent to the main objective of this study, which is to evaluate the combined impacts of climate and socioeconomic changes on likely future water security in the Himalayan basin, India. The future climate was projected by Multi-model Ensembles under the Representative Concentration Pathway (RCP) 4.5 scenario. Land use projection under the Shared Socioeconomic Pathway (SSP) 1 scenario was performed using Markov Chain, whose transition probabilities were derived using multi-layer perceptron neural networks. The results showed that future annual precipitation and temperature at the downstream part will increase from baseline by $5 \%-10 \%$ and $1.0^{\circ} \mathrm{C}-1.55^{\circ} \mathrm{C}$, respectively. The land use projections showed that irrigated areas will decrease for Punjab by $10 \%-30 \%$ and Haryana by $5 \%-10 \%$ due to the increase in urbanisation, whereas it will be increased in Rajasthan by $12 \%-18 \%$. Consequently, the annual irrigation water demand was found to be decreased by $10 \%$ for Punjab and $5 \%$ for Haryana, while it will be increased by $13 \%$ for Rajasthan. Eventually, the obtained findings will be beneficial for planning strategies to ensure water security in the Himalayan region, in particular the Beas-Sutlej basin.
\end{abstract}

Key-words: climate change, multi-model ensembles, global climate models, land use change, reservoir management

\section{INTRODUCTION}

The Himalayas contain one of the largest freshwater resources in the world. The region is a source of ten major river systems that include the Indus and Ganges providing water for irrigation, hydropower generation, and domestic consumption for more than $20 \%$ of the world's population (Mukherji et al., 2015). However, climate change and rapid socio-economic growth are threatening the quality and quantity of the region's water resources (Dau and Kuntiyawichai, 2020).

For India, the continued population growth is increasingly noticeable which may significantly affect the water security in the country. For instance, India is currently the world's second most populous country but is expected to surpass China within the next few decades (Samir et al., 2018). Goyal and Surampalli (2018) stated that current 1.2 billion Indian population have experienced tremendous economic growth in the last 20 years with only $4 \%$ and $9 \%$ of the world's water resources and arable land, respectively. Such a phenomenal growth of the population can only lead to higher domestic, industrial and agricultural water demands (Dau et al., 2021a).

\footnotetext{
${ }^{1}$ Institute for Infrastructure and Environment, Heriot-Watt University, Edinburgh EH14 4AS, UK, infohquan@gmail.com

2* Sustainable Infrastructure Research and Development Centre, Department of Civil Engineering, Faculty of Engineering, Khon Kaen University, Khon Kaen, 40002, Thailand. Corresponding author: kkitti@kku.ac.th
} 
The total cultivated land in India is approximately $183 \mathrm{M}$-ha (million hectares), which is about $55 \%$ of the total area of the country (FAO, 2015). As per the Central Water Commission, water consumption in Indian agriculture accounted for $85.3 \%$ of the total withdrawal in 2000 with industry, energy, domestic, and other sectors accounting for $1.2 \%, 0.3 \%, 6.6 \%$, and $6.4 \%$, respectively (Mirza and Ahmad, 2005). It is obvious that water demand for agriculture is the sector with the highest water demand, which requires most attention to help if struggling in high demand, is of utmost importance and would consider to be the main focus of this study. Every year, India receives about 4,000 BCM (billion cubic meters) from precipitation including snowfall, with only $48 \%$ of this entering the surface and groundwater bodies, while the remaining 52\% is lost as evapotranspiration (Dhawan, 2017). However, due to lack of adequate infrastructure and inappropriate water management, there is only $20 \%$ out of $48 \%$ of the precipitation is actually used (Dhawan, 2017). The total annual utilizable water resources in the country are 1,123 $\mathrm{BCM}$, whereof, $690 \mathrm{BCM}$ is surface water and $433 \mathrm{BCM}$ is groundwater (IRES, 2020). Groundwater withdrawal is estimated to be $231 \mathrm{BCM}$ annually of which about $90 \%$ is used for irrigation, a much higher proportion than the global average of $40 \%$ (Siebert et al., 2010). In particular, this is a major problem in the northern region of India where groundwater level has fallen at the rate of $2 \mathrm{~cm}$ per year between 2002 and 2013 due to over extraction and poor recharge facility (Asoka et al., 2017).

Climate change is also the main concern for India as shown in several recent studies that average temperatures in the Himalayas have already increased by $0.74^{\circ} \mathrm{C}$ in the past 100 years (Li et al., 2016, Du et al., 2004). This is due to its location in tropical latitudes where relatively high temperatures occur more frequently than in other regions of the world (Manish et al., 2016). Increasing temperatures will result in glacier losses and alteration of the hydrologic balance in the basin as stated by Kulkarni and Karyakarte (2014) that a vast loss in glacier mass from $-9 \pm 4$ Gt.year $^{-1}(1975-1985)$ to $-20 \pm 4$ Gt.year ${ }^{-1}(2000-2010)$. These are significant losses for the major rivers in the region for which glacier currently contributes about $70 \%$ of their runoff (Singh and Bengtsson, 2004).

Referring to the importance of the abovementioned issues, the objective of this study was to assess the possible impacts of climate and socio-economic changes on future water security in the Himalayan basin, India. To achieve its main objective, a more robust methodology for impact assessment was as follows: a statistical downscaling method called "Delta Change" was firstly applied to produce a watershed scale multi-model ensemble projections. The Markov chain modeling was also applied to monitor and predict the future land use pattern of the study area. Thereafter, both changes in climate and land use were then simulated by the WEAP water allocation model to enhance the understanding of future water security trend. For a better understanding of how the future climate will impact the surface water resources in the Himalayan basin, the Multi-model Ensembles (MME) of the Coupled Model Intercomparison Project phase 5 (CMIP5) global climate models, forced with the Representative Concentration Pathway (RCP) 4.5, and the Shared Socioeconomic Pathway (SSP) 1 scenario - were considered. The selection of RCP 4.5 was due to the reduction of fossil fuel consumption, which can minimise a large amount of the carbon dioxide emission. In addition, the feedbacks from stakeholders, i.e. scientists from 3 different projects (CHANSE, UPSCAPE, and SusHi-Wat), policy-makers, and farmers, also suggested the SSP1 scenario since India has set a target to increase its renewable energy capacity of $175 \mathrm{GW}$ by mid-century (Chaturvedi et al., 2020). The MME is a promising way to reduce uncertainties in present-day simulations and to improve confidence in some aspects of future climate projections (Wang et al., 2018). The approach was used for this study because it shows the uncertainty across models in simulating the climate (Tebaldi and Knutti, 2007), which can be more reliable than using a single model (Dong et al., 2015). It is a matter of fact that the selected climate models operate at very coarse spatial scales, a technique called statistical downscaling was then used to derive climate information at finer spatial resolution from coarser spatial resolution GCM output by combining climate model projections with local/regional observations (Dau et al., 2017) (Note: this research used the statistical downscaling technique due to its efficient diagnostics to assess the GCMs reliability (Benestad and Haugen, 2007), with reasonable results comparable to dynamical downscaling (Penalba et al., 2014). 


\section{STUDY AREA}

The study area is the Beas-Sutlej basin, in the Western Himalayas, India, where about 2,673 $\mathrm{km}^{2}$ (12\% of the basin area) is covered by permanent snowfields and glacier (Singh and Bengtsson, 2004) (Fig. 1). The Beas basin lies entirely in India with a total area of $12,569 \mathrm{~km}^{2}$ of which $780 \mathrm{~km}^{2}$ is situated in the upper part under permanent snow (Jain et al., 2007). The Sutlej basin covers an area of $56,860 \mathrm{~km}^{2}$ with $22,275 \mathrm{~km}^{2}$ of this lying in India. There are two main reservoirs, i.e. the Pong and the Bhakra, that serve domestic, irrigation, hydropower generation, and flood control purposes (Adeloye et al., 2019). Climatologically, the basin is mostly influenced by tropical monsoon in which four seasons can be distinguished, i.e. winter (December - February), summer (March - May), rainy (June - August), and autumn (September - November). The mean annual precipitation is estimated between $1,200 \mathrm{~mm}$ and $1,800 \mathrm{~mm}$, whereas the average temperature ranges from $-10^{\circ} \mathrm{C}$ to $+10^{\circ} \mathrm{C}$ depending on the altitude varying from 100 to 7,000 meters above mean sea level (MSL). There are large-scale schemes located in the irrigated lands or the so-called "command areas" in the States of Punjab, Haryana and Rajasthan (see Fig. 1). According to the information from Dhawan (2017), it can be summarized that rice, wheat and sugarcane are the largest India's crop production with the proportion of $90 \%$ of country-wide production, in which they are considered to be the most water consuming crops.

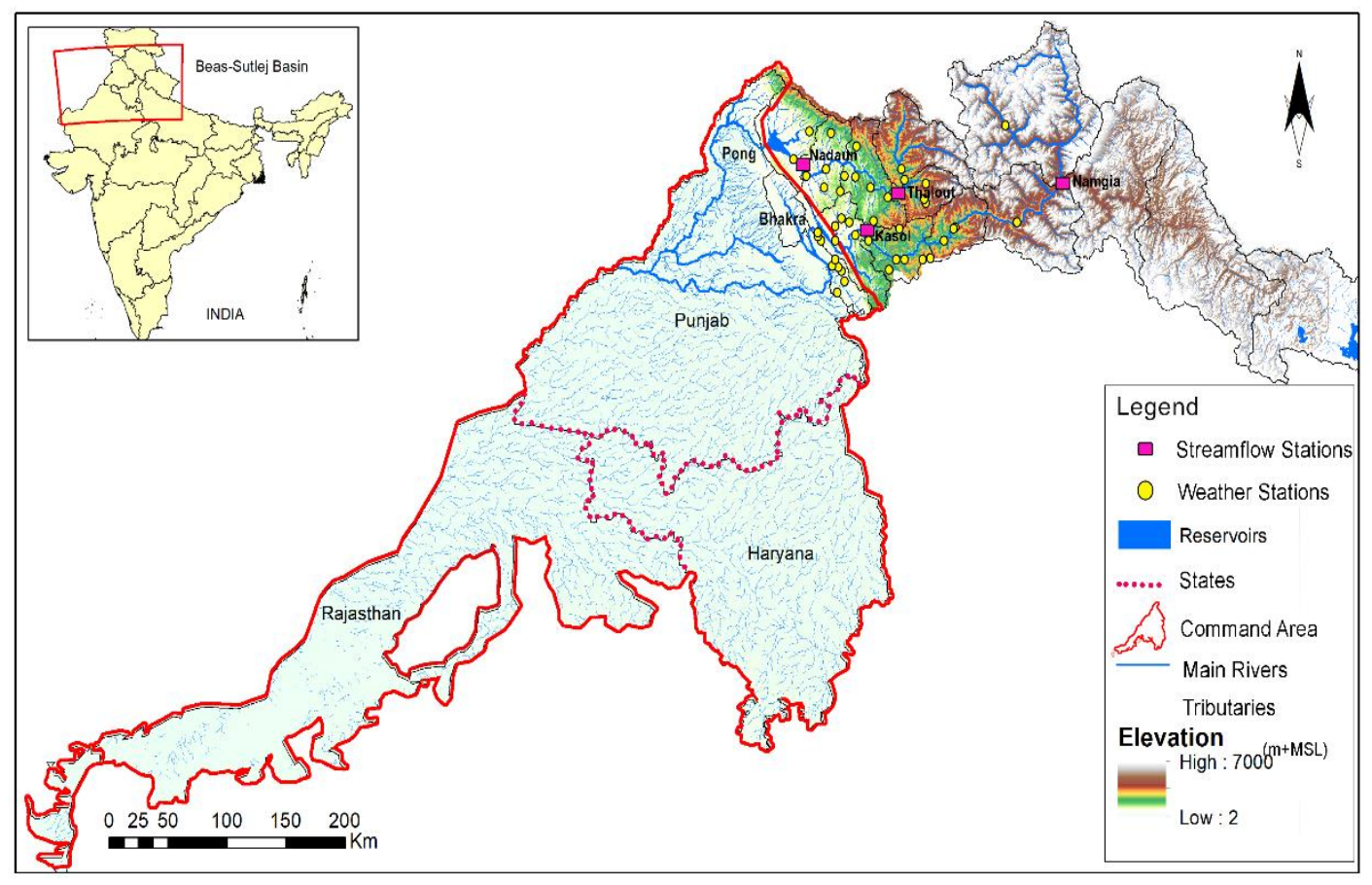

Fig. 1 The Beas-Sutlej River Basin.

\section{DATA AND METHODS}

It is of paramount importance to provide detailed information about the potential impacts of climate and socio-economic changes in order to enhance preparedness and adaptation strategies in the Himalayan basin, India, where the information about climate projections and hydro-climatic impacts is somehow questionable. To make it clear, Fig. 2 shows the workflow of this study, in which each component was described in the following sub-sections. 


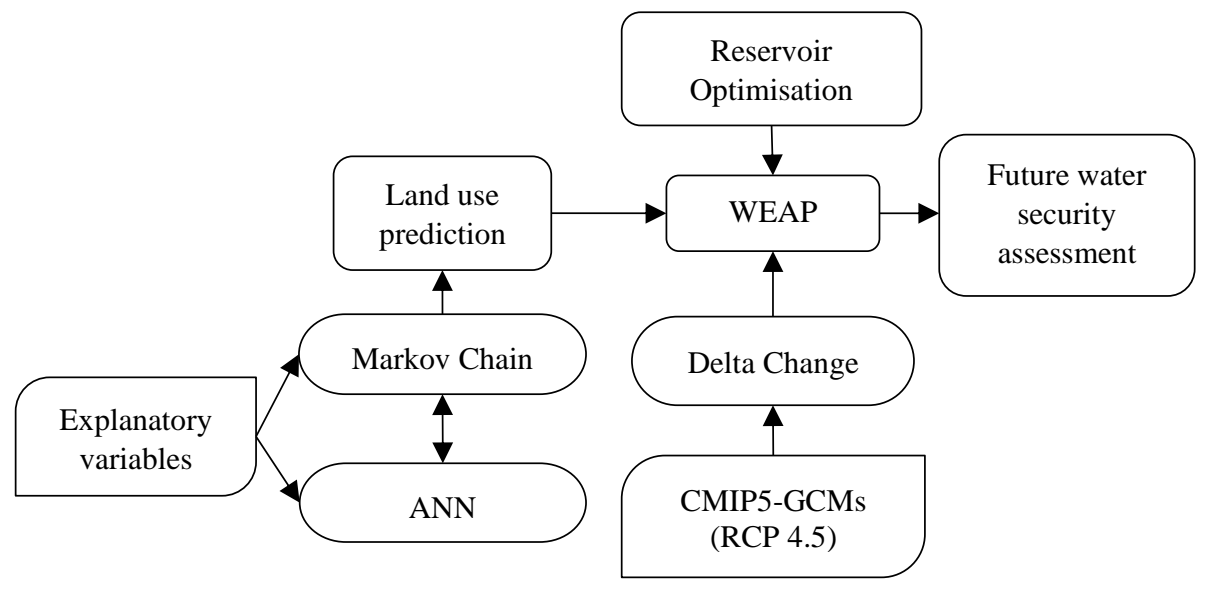

Fig. 2 The workflow for assessing the climate and socio-economic change impacts on future water security in

\subsection{Data collection} the Himalayan basin, India

The ERA-Interim historical reanalysis data over 1990 to 2007 (baseline) used in this study were dynamically downscaled to $5 \mathrm{~km}$ x $5 \mathrm{~km}$ using the Weather Research and Forecasting (WRF) model forced with atmospheric initial and boundary conditions for selected CMIP5 GCMs (Taylor et al., 2012) as a baseline. Table 1 summarises all the CMIP5 GCM models used in this study, including the grid resolutions which represent the distance between adjacent grid points in degrees.

CMIP5 models and their grid resolutions

Table 1.

\begin{tabular}{|c|c|c|c|c|c|c|c|}
\hline \multirow{2}{*}{ No. } & \multirow{2}{*}{ Model acronym } & \multicolumn{2}{|c|}{ Atmospheric grid $\left({ }^{\circ}\right)$} & \multirow{2}{*}{ No. } & \multirow{2}{*}{ Model acronym } & \multicolumn{2}{|c|}{ Atmospheric grid $\left({ }^{\circ}\right)$} \\
\hline & & Latitude & Longitude & & & Latitude & Longitude \\
\hline 1 & ACCESS1.0 & 1.2500 & 1.8750 & 19 & GISS-E2-H-CC & 2.0000 & 2.5000 \\
\hline 2 & ACCESS1.3 & 1.2500 & 1.8750 & 20 & GISS-E2-HP1 & 2.0000 & 2.5000 \\
\hline 3 & BCC-CSM1.1 & 2.7906 & 2.8125 & 21 & GISS-E2-R-CC & 2.0000 & 2.5000 \\
\hline 4 & BCC-CSM1.1(m) & 2.7906 & 2.8125 & 22 & HadGEM2-AO & 1.2500 & 1.8750 \\
\hline 5 & BNU-ESM & 2.7906 & 2.8125 & 23 & HadGEM2-CC & 1.2500 & 1.8750 \\
\hline 6 & CanESM2 & 2.7906 & 2.8125 & 24 & HadGEM2-ES & 1.2500 & 1.8750 \\
\hline 7 & CCSM4 & 0.9424 & 1.2500 & 25 & INM-CM4 & 1.5000 & 2.0000 \\
\hline 8 & CESM1(BGC) & 0.9424 & 1.2500 & 26 & IPSL-CM5A-LR & 1.8947 & 3.7500 \\
\hline 9 & CESM1(CAM5) & 0.9424 & 1.2500 & 27 & IPSL-CM5A-MR & 1.2676 & 2.5000 \\
\hline 10 & CMCC-CM & 0.7484 & 0.7500 & 28 & IPSL-CM5B-LR & 1.8947 & 3.7500 \\
\hline 11 & CMCC-CMS & 3.7111 & 3.7500 & 29 & MIROC-ESM & 2.7906 & 2.8125 \\
\hline 12 & CNRM-CM5 & 1.4008 & 1.40625 & 30 & MIROC-ESM-CHEM & 2.7906 & 2.8125 \\
\hline 13 & CSIRO-Mk3.6.0 & 1.8653 & 1.8750 & 31 & MIROC5 & 1.4008 & 1.4063 \\
\hline 14 & EC-EARTH & 1.1215 & 1.1250 & 32 & MPI-ESM-LR & 1.8653 & 1.8750 \\
\hline 15 & FGOALS-g2 & 2.7906 & 2.8125 & 33 & MPI-ESM-MR & 1.8653 & 1.8750 \\
\hline 16 & GFDL-CM3 & 2.0000 & 2.5000 & 34 & MRI-CGCM3 & 1.1215 & 1.1250 \\
\hline 17 & GFDL-ESM2G & 2.0225 & 2.0000 & 35 & NorESM1-M & 1.8947 & 2.5000 \\
\hline 18 & GFDL-ESM2M & 2.0225 & 2.5000 & 36 & NorESM1-ME & 1.8947 & 2.5000 \\
\hline
\end{tabular}


The observed discharges and reservoir data, i.e. bathymetry, inflow/outflow, and hydropower capacity, were gathered from the Bhakra and Beas Management Board (BBMB) and relevant agencies. Land cover maps at $300 \mathrm{~m}$ resolution for the years 2000, 2005, and 2010 provided by the European Space Agency Climate Change Initiative (ESA-CCI) were utilized for explaining the variations of land use and vegetation due to social-economic changes.

Domestic water demand was estimated from historical population in 2000 obtained from the Census of India and projected population (1-km grid cells) re-downscaled by Gao (2017) under SSPs. The SSPs (O'Neill et al., 2014) under five different pathways, i.e. sustainability-SSP1, middle of the road-SSP2, regional rivalry-SSP3, inequality-SSP4, and fossil-fuelled development-SSP5, were used for describing broad socio-economic trends that could shape future society. Accordingly, projected population under SSP1 scenario was used for this study.

\subsection{Global climate downscaling under RCP 4.5 using Delta Change approach}

A widely used technique called Delta Change suggested by (Lenderink et al., 2007) was chosen to correct the biases associated with the downscaled future projection data produced by a high resolution $(5 \mathrm{~km}) \mathrm{WRF}$ simulation obtained from (Bannister et al., 2019). The WRF model was forced by 18 baseline years of ERA-Interim historical reanalysis climate data $(1990$ - 2007) (Note: more details related to WRF model can be seen in (Bannister et al., 2019). For each GCM, the future projected climate data for each time horizon, e.g. mid-century $(2033-2050)$, end-century (2083 $2100)$, etc., was carried out in order to obtain monthly delta changes in precipitation $\left(\triangle P^{G C M}\right)$ and temperature $\left(\triangle T^{G C M}\right)$ (Note: the selected time horizons were chosen in order to take into account the medium- and long-term effects of climate change on glacier melting, as suggested by previous studies (Nepal, 2016, Dau and Adeloye, 2021, Maurer et al., 2019). These changes were then applied to the WRF baseline $(1990$ - 2007) for providing the corresponding high-resolution future climate projection as shown in Eqs. (1) and (2).

$$
\begin{gathered}
P_{m, y}^{F}=P_{m, y}^{H^{W R F}} \times \Delta P_{m}^{G C M} \\
T_{m, y}^{F}=T_{m, y}^{H^{W R F}}+\Delta T_{m}^{G C M}
\end{gathered}
$$

where, $P$ and $T$ are the downscaled precipitation and temperature in month $m$ and year $y$, respectively; $F$ and $H$ refer to a future time slice and historical period, respectively; $\Delta P_{m}^{G C M}$ and $\triangle T_{m}^{G C M}$ are changes between the future and baseline periods for each CMIP5 GCM which can be calculated as follows.

$$
\begin{aligned}
\Delta P_{m}^{G C M} & =\left(\frac{P_{m}^{F^{G C M}}}{P_{m}^{H^{G C M}}}\right) \\
\Delta T_{m}^{G C M} & =\left(T_{m}^{F^{G C M}}-T_{m}^{H^{G C M}}\right)
\end{aligned}
$$

A simple statistical test was further carried out as given in Eq. (5). Skew coefficient (G) was then compared with the approximate $95 \%$ confidence limits for zero skew between the $-1.96 S E$ and $+1.96 S E$ interval, where $S E$ is standard error of estimate of sample skew coefficient, approximately equal to $\sqrt{\frac{6}{n}}$. If the skew coefficient falls within the $95 \%$ confident limits, then the null hypothesis that the skew is zero is not rejected (symmetrical distribution); otherwise, they are asymmetrical distribution.

$$
G=\frac{n \sum_{i=1}^{n}\left(y_{i}-\mu_{y}\right)^{3}}{(n-1)(n-2) \sigma_{y}^{3}}
$$

where, $G$ is skew coefficient; $n$ is sample size; $\mu_{y}$ and $\sigma_{y}$ are mean and standard deviation of $y$, respectively 


\subsection{Land use change projection}

The projection of land use changes was performed with the spatial model coupling Markov Chains proposed by (Marko et al., 2016). The Markov Chain model contains two main processes: the transition probability matrix $(\tau)$ describes the probability of land cover changes from one period to another (Eq. (6)); and a projection phase to determine the future land change patterns based on the information given in the first stage (Eq. (7)):

$$
\begin{gathered}
\tau=\left(\begin{array}{ccc}
\tau_{11} & \cdots & \tau_{1 n} \\
\vdots & \ddots & \vdots \\
\tau_{n 1} & \cdots & \tau_{n n}
\end{array}\right) \quad \sum_{j=1}^{n} \tau_{i j=1 ;} \quad i, j \in \mathrm{N} \\
0 \leq \tau_{i j} \leq 1 \\
\theta_{(t+1)}=\tau \times \theta_{\mathrm{t}}
\end{gathered}
$$

where, $\tau$ is the transition probability matrix; $\tau_{i j}$ represents the probability of the system transitioning from land use type $i$ to $j ; n$ is the total number of land use types; and $\theta_{t}$ and $\theta_{t+1}$ are land use maps at time $t$, and $t+1$.

The determination of transition probability matrix requires relationship between land use patterns and factors known to influence them. Explanatory variables such as topographic conditions (elevation, slope, distance to urban, rivers, roads), and human interaction (population) were used to explain potential transition changes in land use. These driving factors were initially validated to determine the associations with each of classes in land use map using the Cramer's $V$ statistic (Cramér, 1946) in Eq. (8).

$$
V=\sqrt{\frac{\chi^{2} / n}{\min (k-1, r-1)}}
$$

where $\chi$ is chi-squared; $n$ is the total of observations; and $k$ and $r$ are number of column and row in land use maps.

The transition probability can be predicted using multi-layer perceptron (MLP) in neural network (Park and Lek, 2016). In the neural network architecture, explanatory variables were defined as nodes of the input layer, while land change pattern map between 2000 and 2005 was analysed to determine the observed potential transition probability that forms the nodes in the output layer. The study used $50 \%$ of the sample size for training and the remaining $50 \%$ for testing. Land cover maps for the years 2000 and 2005 were used for the training and testing and that for 2010 was used for validation. Numbers of hidden layer were determined based on the traditional trial and error approach.

The model performance was assessed using $R^{2}$. The Kappa Index of Agreements (Pontius, 2002) were also used to compare the observed "proportion correction" to the expected "proportion correction" due to chance for land use maps in 2010, in which a Kappa value greater than 0.75 is considered as very good to excellent agreement (Landis and Koch, 1977).

\subsection{Integrated reservoir operating and management}

In this study, a reservoir operation simulation program in WEAP (Water Evaluation And Planning) model, which was developed by the Stockholm Environment Institute (Sieber and Purkey, 2011) and has been widely used in many regional water allocation problems (Dau et al., 2021a, Dau et al., 2018), was applied for determining optimal water allocation for each monthly time step based on demand priorities and supply preference. The optimal rule curves were developed based on Genetic Algorithm (GA), for a multiple purpose and combined within a single objective function (Eq. (9)), covering of irrigation water supply, hydropower, and flood control. As a result, the Upper Rule Curve (URC) and Lower Rule Curve (LRC) can be specified based on 24 decision variables for the design of reservoir release policies. 


$$
f=\min \sum_{i=1}^{2} \sum_{t=1}^{T}\left[\left(\frac{D_{t}^{i}-R_{t}^{i}}{D_{t}^{i}}\right)^{2}+\left(\frac{P_{\max }^{i}-P_{t}^{i}}{P_{\max }^{i}}\right)^{2}+\left(\frac{\max Z_{t}^{i}-Z\left(L R C_{m}^{i}\right)}{Z\left(U R C_{m}^{i}\right)-Z\left(L R C_{m}^{i}\right)}\right)^{2}\right]
$$

subject to the constraints:

Water balance:

$$
S_{t+1}=S_{t}+Q_{t}-R_{t}-E V_{t}
$$

Hydropower generation:

$$
\begin{aligned}
& P_{\text {min }} \leq P_{t} \leq P_{\text {max }} \\
& P_{t}=\min \left(\eta g \rho R_{t} \overline{H_{t}}, P_{\text {max }}\right)
\end{aligned}
$$

Flood control:

$$
\begin{aligned}
& Z_{t}\left(L R C_{m}\right) \leq Z(t) \leq Z_{t}\left(U R C_{m}\right) \\
& \max Z=\min \left[\left(a \times S_{t}^{3}\right)+\left(b \times S_{t}{ }^{2}\right)+\left(c \times S_{t}\right)+d, Z\left(U R C_{m}\right)\right]
\end{aligned}
$$

Irrigation water supply:

$$
\text { If }\left\{\begin{array}{l}
W A_{t} \geq U R C_{m}, R_{t}=S_{t}+Q_{t}-E V_{t}-U R C_{m} \& E R_{t}=R_{t}-D_{t} \\
\text { else, } \quad R_{t}=0
\end{array}\right.
$$

where $D_{t}^{i}$ and $R_{t}^{i}$ are respectively allocated demand and actual release during time $t$ of the reservoir $i$; $P_{t}$ is hydropower generation at period $t ; P_{\min }$ and $P_{\max }$ are minimum and maximum plant power capacities; $\max _{t}$ is maximum reservoir water level at period $t ; L R C_{m}$ and $U R C_{m}$ are upper and lower limits of rule curves in month $m ; S_{t}$ and $S_{t+1}$ are respectively initial and final storage; $Q_{t}$ is inflow; $\eta$ is overall efficiency factor; $g$ is acceleration of gravity; $\rho$ is water density; $\overline{H_{t}}$ is hydraulic head of dam; $E V_{t}$ is net evaporation in volume unit; $W A_{t}$ water availability at the beginning of time $\left(\mathrm{WA}_{\mathrm{t}}=\mathrm{S}_{\mathrm{t}}+\mathrm{Q}_{\mathrm{t}}\right) ; E R_{t}$ is excess release; $a, b, c, d$ are the constant coefficients obtained from the storage - elevation curve for each reservoir given at the Pong (Eq. (16)) and Bhakra reservoirs (Eq. (17)):

$$
\begin{aligned}
& Z_{t, \text { Pong }}=\left(3^{-10} \times S_{t}^{3}\right)+\left(5^{-6} \times{S_{t}}^{2}\right)+\left(0.031 \times S_{t}\right)+349.14 \\
& Z_{t, \text { Bhakra }}=\left(9^{-11} \times{S_{t}}^{3}\right)+\left(2^{-6} \times{S_{t}}^{2}\right)+\left(0.0263 \times S_{t}\right)+393.5
\end{aligned}
$$

\subsection{Simulation of water resources}

For examining water allocation and demand in the study area, the WEAP model was applied. In addition, the optimised rule curves, which define the top of conservation storage zones and the top of buffer storage zones, were also considered in the WEAP to estimate water allocation in the basin. 
Regarding the runoff volume calculation for the upstream mountainous area, the Rainfall-Runoff Soil Moisture (RRSM) method, which relies on empirical functions for describing evapotranspiration, surface and sub-surface runoffs, and deep percolation for a watershed unit, was used (Note: groundwater component was ignored in the simulation). This method considers two soil layers: the upper compartment that simulates surface runoff when forced with rainfall and evapotranspiration; and the lower soil layer where baseflow routing to the river and soil moisture changes are simulated (Yates et al., 2005).

In terms of mass balance of glacial systems, by considering the accumulation of glacier to be uniform, the glacier volume was then calculated by multiplying the ice depth with the sub-basin area covering by snow and ice (Sieber and Purkey, 2011). The projected glacier area was obtained from a recent study by (Prasad et al., 2019) for measuring ice and snow melt at basin scale.

For the downstream irrigated command area, the MABIA (MAitrise des Besoins d'Irrigation en Agriculture) method was employed for estimating irrigation demands (Sieber and Purkey, 2011). The MABIA determines the actual evapotranspiration $\left(E T_{c}\right)$ from the reference crop evapotranspiration $\left(E T_{0}\right)$ using "dual" $K_{c}$ method (see Eq. (18)), where $K_{c b}$ is basal crop coefficient, $K_{e}$ is evaporation from the soil surface.

$$
E T_{c}=\left(K_{c b}+K_{e}\right) E T_{0}
$$

\section{RESULTS AND DISCUSSIONS}

\subsection{Probability density distribution function for climate data}

Based on the skew coefficient $(\mathrm{G})$, it is possible to determine the distributions of precipitation and temperature revealed by the multi-model ensemble (MME) dataset. The statistical weather parameter reveals that future monthly precipitation in the Himalayan region would dominate by symmetrical and asymmetrical distributions varying from month to month. It was found that the monthly precipitation has a symmetrical distribution for the months of Feb, Mar, Jun, Aug, Nov, and Dec, which represents a distribution with a shape similar to a normal distribution, while the months of Jan, Apr, May, Jul, Sep, and Oct with an asymmetrical appearance is more closely fitted to the lognormal distribution. In case of annual time-scale, referring to Fig. 3, the precipitation distribution appears as a left-leaning curve, which is positive asymmetry or the so-called right-skewed distribution, for both the mid- and end-century periods. In comparison to the precipitation, the temperature is more symmetrically distributed, and it can accurately be described by a normal distribution.

\subsection{Climate projection for upstream of the basin}

As shown in Fig. 3, the projected mean annual precipitation indicates a rising pattern between $15 \%$ to $20 \%$ across the GCMs, in which the highest occurrence indicated by the BNU-ESM model and lowest intensity represented by the GFDL-ESM2G model. The precipitation seems to be increased during the monsoon season, with the average rainfall of approximately $300 \mathrm{~mm}$ in July. In comparison to the baseline period, the average annual temperature shows the increase between $3.5^{\circ} \mathrm{C}$ and $5.0^{\circ} \mathrm{C}$ in the future across the GCMs, with the highest rise indicated by the GFDL-CM3 model projection by $7.0^{\circ} \mathrm{C}$. Interestingly, the obtained finding corresponds to the recent studies conducted by (Krishnan et al., 2019, Rajbhandari et al., 2018), which concluded that the future annual temperature would reach up to $5^{\circ} \mathrm{C}$ in the Himalayan basin.

The increase in temperature could probably reduce glacier volume in the Himalayan upstream as it was found that the mean annual glacier volume could reduce from approximately 1,403 BCM (baseline) to be 1,197 $\mathrm{BCM}$ in the mid-century (reduce by $-14.5 \%$ ) and $876 \mathrm{BCM}$ in the end-century (reduce by $-37.5 \%$ ). In contrast, the glacier melting would increase the runoff volume that enters the Pong and Bhakra reservoirs. As a consequence, the mean annual runoff in the Beas River would increase to $10.00 \mathrm{BCM}$ in comparison to the baseline (8.77 $\mathrm{BCM})$, whereas the Sutlej River would also increase to $23.00 \mathrm{BCM}$ compared to its baseline (21.71 $\mathrm{BCM}$ ) across the GCMs projection. 

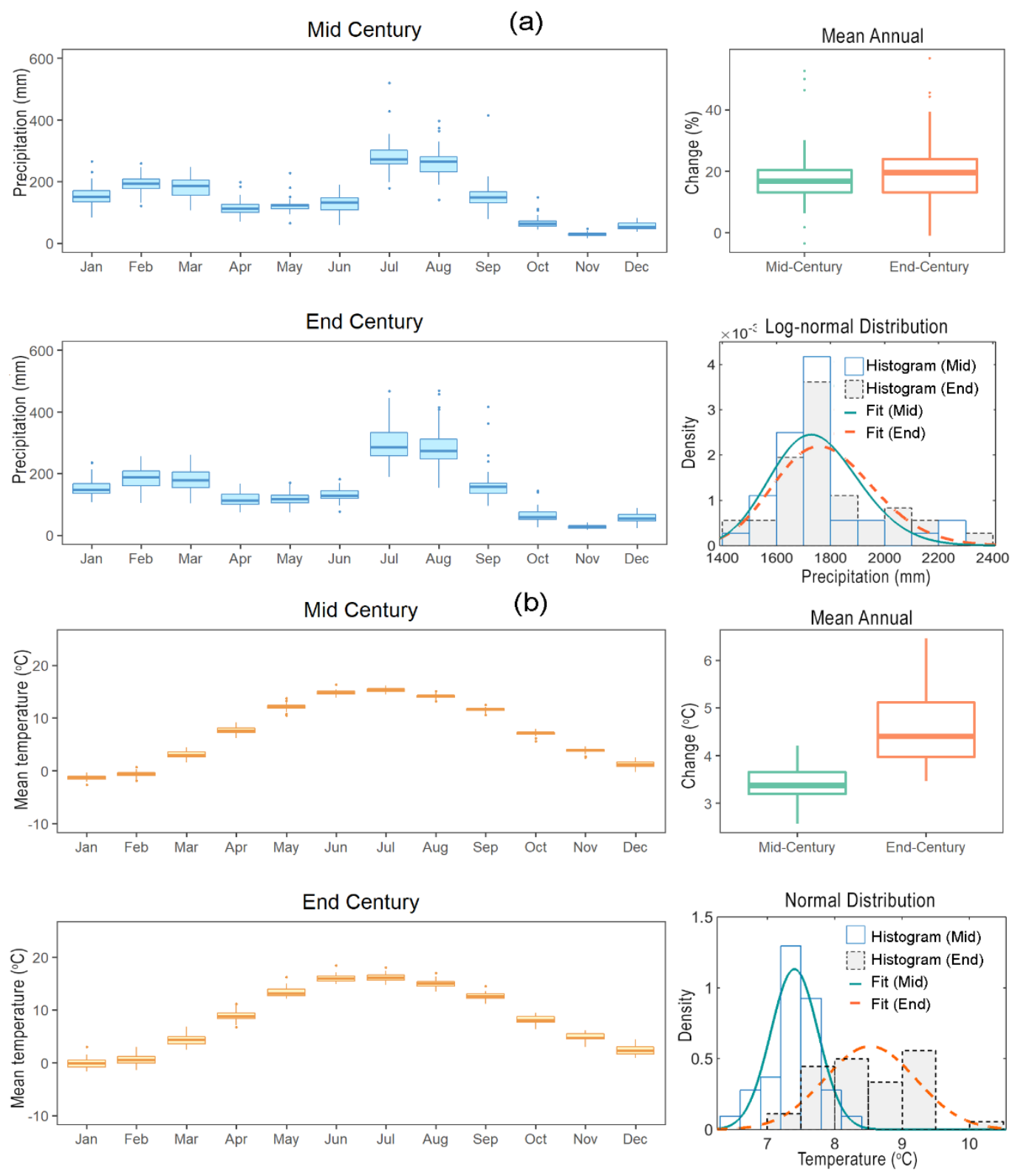

Fig. 3 The mean monthly climate data, annual changes, and annual probability density function for (a) precipitation and (b) temperature at the upstream

\subsection{Climate projection for downstream of the basin}

The climate projections were averaged across the GCM models and presented for each state in the command area. Referring to the downscaled results, it was revealed that the downstream would experience a warmer future climate, in which the mean annual precipitation would increase between $5 \%$ and $10 \%$ in the mid- and end-centuries in comparison to the baseline, with high intensity during the monsoon season. By considering both mid- and end-centuries (Fig. 4), the result suggests that future monthly precipitation will increase from its baseline, i.e. in Punjab from $180 \mathrm{~mm}$ to $200 \mathrm{~mm}$, in Haryana from $130 \mathrm{~mm}$ to $150 \mathrm{~mm}$, and in Rajasthan from $70 \mathrm{~mm}$ to $80 \mathrm{~mm}$. 
In addition, the maximum temperature will also increase from its baseline, i.e. in Rajasthan from $23.89^{\circ} \mathrm{C}$ to $25.44^{\circ} \mathrm{C}$, in Punjab from $22.84^{\circ} \mathrm{C}$ to $24.39^{\circ} \mathrm{C}$, and in Haryana from $22.87^{\circ} \mathrm{C}$ to $24.53^{\circ} \mathrm{C}$. The aforesaid finding expresses the potential severe impacts for the future water resources in Rajasthan State, which would affect the extensive agricultural plots due to lacking of rainfall and surface water availability.
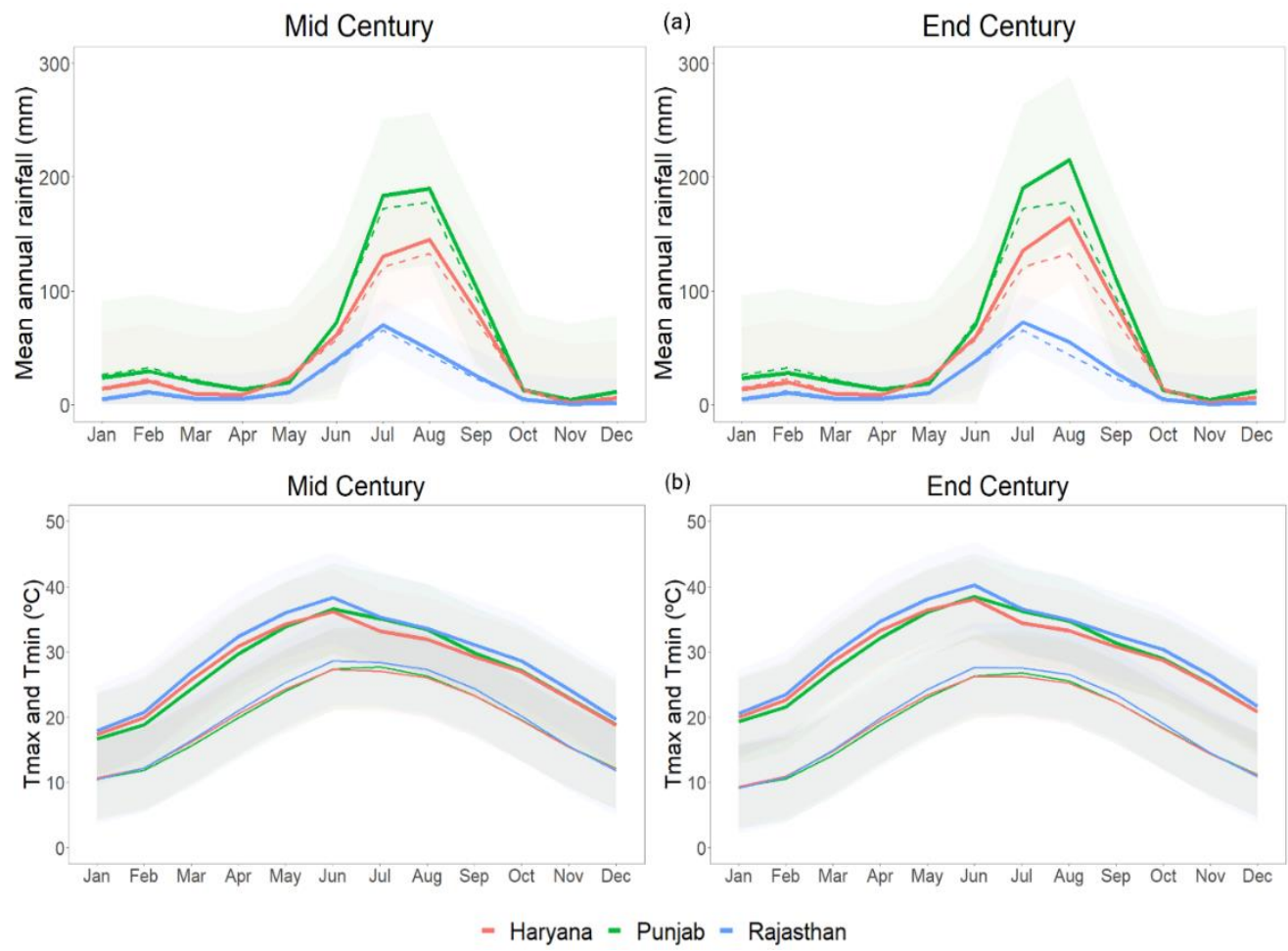

Fig. 4 Ensemble mean of monthly (a) rainfall (dotted lines are the baseline) and (b) maximum \& minimum temperature in irrigated areas

\subsection{Projections for socio-economic and land use changes}

The projected population under SSP1 scenario for the Beas-Sutlej basin expresses a rapid growth in the mid-century between $35 \%$ and $45 \%$ but it would be decreased by the end-century between $10 \%$ and $20 \%$ compared to the baseline (year 2000). Based on the analysis, the population density was expected to expand significantly at the downstream. Obviously, the ratio between rural and urban population in Punjab, Haryana, and Rajasthan States was found to be changed remarkably from 66/34, $71 / 29$, and $77 / 23$, respectively in 2001 to $63 / 37,65 / 35$, and $75 / 25$, respectively in 2011 (CensusInfo, 2011). It can be said that the rapid increase in population together with changes in migration consequences could potentially increase the demand for downstream domestic water consumption.

Regarding future land use changes, there are several drivers used for land use projections. In details, the road network was found to be one of the main direct drivers since it provides the access to previous remote areas and also promotes anthropogenic disturbance near roadways. Secondly, the urban center was also the main contributor to urban population growth, which might lead to be more susceptible to land use change. Moreover, environmental gradients such as changing temperature and precipitation with altitude, was also found to be a good predictor to the area suitable for agriculture and vulnerable to conversion to agricultural land. 
Lastly, the slope is also of paramount importance to determine the land useful for human development, for instance, agriculture and building require a fairly gentle slope. As a result, the $V$ statistic test results indicated that elevation (0.375), population (0.260), slope $(0.247)$ and distance to cities $(0.199)$ are a very strong correlation with the land use change, while distance to rivers $(0.134)$ and roads (0.089) showed moderate and weak correlations, respectively. Thereafter, these explanatory variables were modeled with the "static" role in model structure, which is a function of certain fixed (unchanging) driving factors for expressing aspects of basic suitability for the transition under consideration. The transition probability prediction revealed a good performance in the neural network, i.e. $R^{2}$ index greater than 0.83 and the Kappa index of agreement of $98 \%$ when compared the projected to its observed land use map in 2010 (Fig. 5).

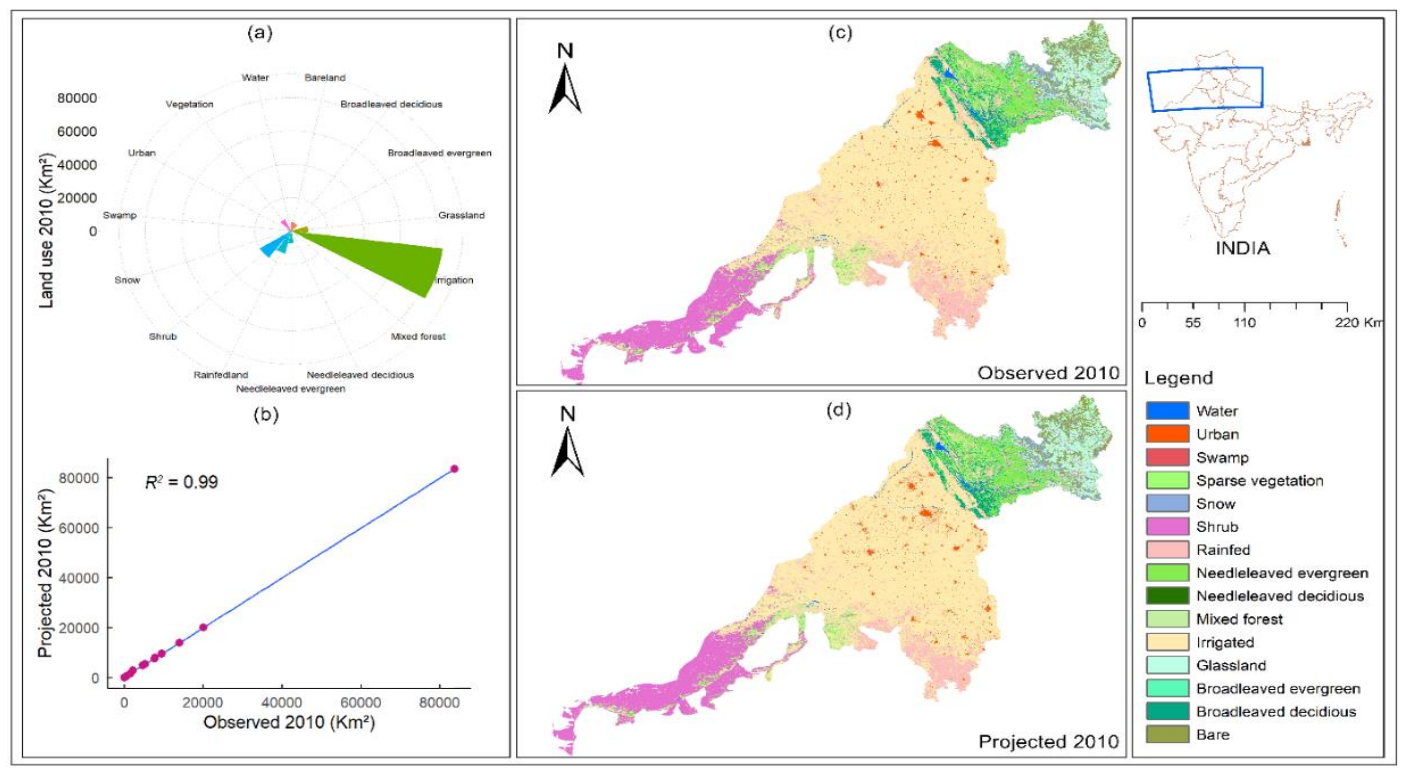

Fig. 5 Detailed information about (a) land use types, (b) correlation between 2010 observed and projected areas, (c) 2010 observed land use map, and (d) 2010 projected land use map.

It was found that the irrigated land would likely be decreased in the future and switched to urban areas. In details, Punjab and Haryana irrigated lands would decrease by $15 \%$ to $30 \%$ and 5\% to $10 \%$, respectively, compared to the baseline. Conversely, irrigated land in Rajasthan is expected to expand by about $12 \%$ to $18 \%$ in the future in comparison to the baseline period, as can clearly be seen from the historical data during 1995 to 2010 that the expansion of arable land was mainly at the expense of shrub vegetation. Importantly, the insights gained from this land use change study is somehow in consistent with the findings of (Naikoo et al., 2020) who revealed that the major change from agriculture to urban areas also occurred in New Delhi located at the downstream of Haryana and Punjab States, which experienced the decrease from $12 \%$ to $32 \%$ during the period of 1990 to 2018 . Correspondingly, Meer and Mishra (2020) also found a similar trend in land use change during 1979 to 2018 in Northern India where the urban coverage expanded significantly over the region possibly due to increased population, while the agricultural areas decreased by $55 \%$.

\subsection{Future projection for water resources system}

Prior to further WEAP model simulations for water demands and supplies and water storage and releases from the reservoirs, the calibration and validation processes were executed by comparing the monthly simulated and observed discharge and reservoir inflow at four available streamflow stations and two reservoir sites, respectively (see Fig. 1 for their locations). 
Referring to Fig. 6, it is apparent that the simulated data is consistent with the observed values for the entire simulation periods. In addition to graphical technique, statistical indicators, i.e. Pearson's correlation coefficient (r) (Pearson, 1895) and Nash-Sutcliffe Efficiency (NSE) (Nash and Sutcliffe, 1970) were also used to evaluate the WEAP model performance.
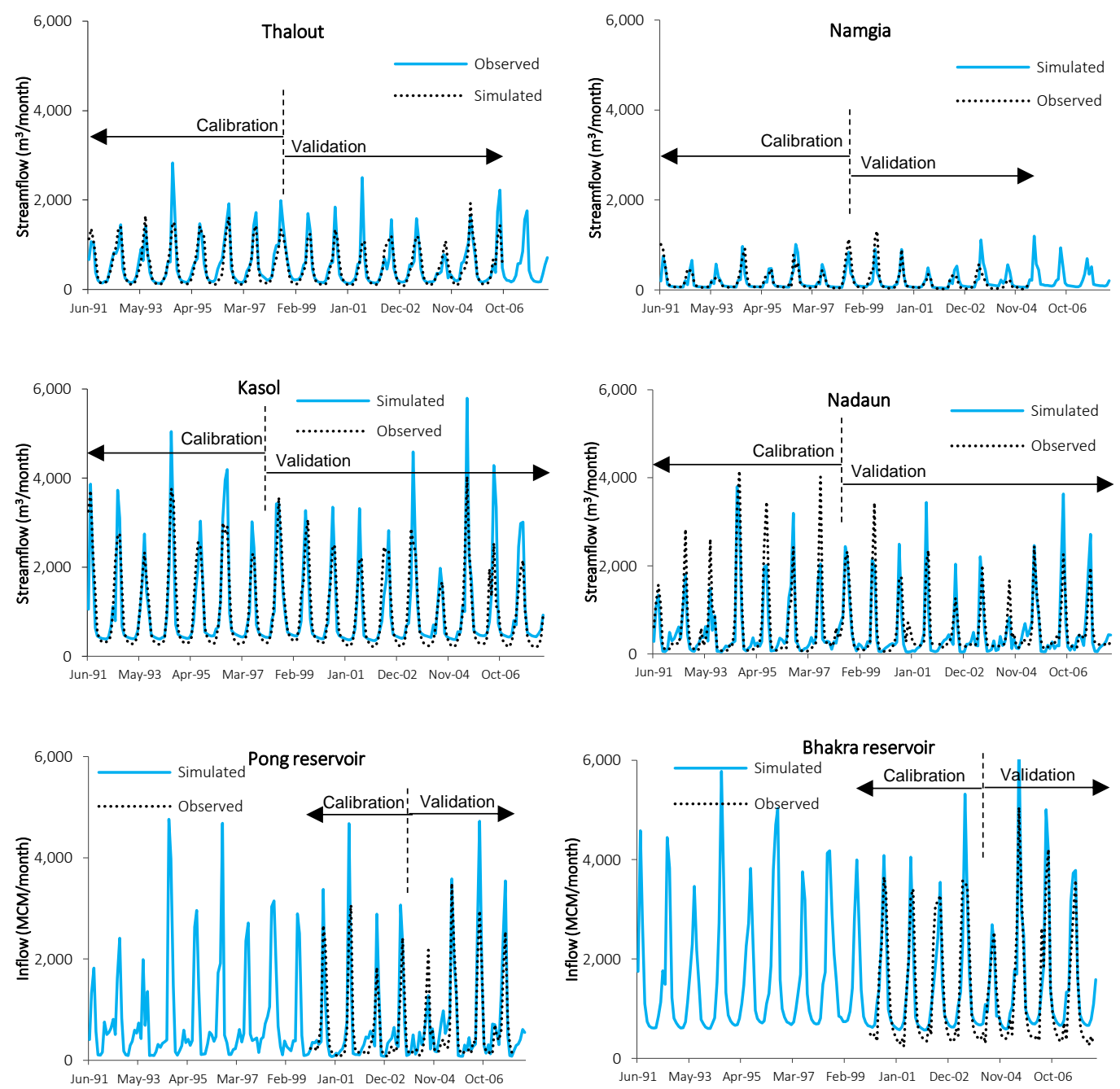

Fig. 6 Monthly simulated and observed streamflow during calibration and validation at different monitoring stations.

With respect to Table 2, based on Moriasi et al. (2007), the WEAP showed acceptable results with the values of $r$ and NSE $>0.50$ for both calibration and validation. Therefore, it can be said that the WEAP model is well calibrated and can be used to evaluate water allocation in the study area according to different scenarios. Thereafter, the WEAP model in association with the optimal rule curves for Pong and Bhakra reservoirs under joint operation, was applied for water allocation simulations. In this case, the reservoir management zone called conservation zone (the space between LRC and URC) was defined to freely release the water from the conservation pool to fully meet downstream requirements, in which when the reservoir storage level falls inside the buffer zone (the space between dead storage and LRC), the flow release rate is limited using a buffer coefficient $(\alpha)$ with the value between zero and one to limit the amount of water available for each month at critical 
conditions in the reservoir. In this study, the value of $\alpha$ of 0.1 was defined for the Pong and Bhakra reservoirs, which indicates that the reservoir release will be reduced by $10 \%$ if the storage level falls into the buffer zone.

Table 2.

Calibration and validation results of WEAP model

\begin{tabular}{|l|l|l|c|c|}
\hline \multirow{2}{*}{ Station } & \multirow{2}{*}{ Process } & \multirow{2}{*}{ Period } & \multicolumn{2}{|c|}{ Fitness criterion } \\
\cline { 4 - 5 } & & & $\mathbf{r}$ & NSE \\
\hline \multirow{2}{*}{ Thalout } & Calibration & $1991-1998$ & 0.89 & 0.74 \\
\cline { 2 - 5 } & Validation & $1999-2005$ & 0.88 & 0.61 \\
\hline \multirow{2}{*}{ Namgia } & Calibration & $1991-1998$ & 0.76 & 0.56 \\
\cline { 2 - 5 } & Validation & $1999-2004$ & 0.70 & 0.50 \\
\hline \multirow{2}{*}{ Kasol } & Calibration & $1991-1999$ & 0.89 & 0.77 \\
\cline { 2 - 5 } & Validation & $2000-2007$ & 0.84 & 0.53 \\
\hline \multirow{2}{*}{ Nadaun } & Calibration & $1991-1999$ & 0.90 & 0.80 \\
\hline \multirow{2}{*}{ Pong } & Validation & $2000-2007$ & 0.84 & 0.50 \\
\cline { 2 - 5 } & Calibration & $2000-2004$ & 0.83 & 0.68 \\
\cline { 2 - 5 } & Validation & $2005-2007$ & 0.81 & 0.55 \\
\hline \multirow{2}{*}{ Bhakra } & Calibration & $2000-2004$ & 0.87 & 0.77 \\
\cline { 2 - 5 } & Validation & $2005-2007$ & 0.84 & 0.57 \\
\hline
\end{tabular}

Regarding the increase of future precipitation, glacier melt, and reduction in cultivated land, the mean annual runoff is expected to increase in the Sutlej River (in the range of $3.6 \%$ to $4.67 \%$ ) and Beas River (by $4.73 \%$ to $7.82 \%$ ) in comparison to the baseline. Referring to Fig. 7, the mean monthly runoff in the Beas and Sutlej Rivers is likely to increase from pre-monsoon to monsoon periods.
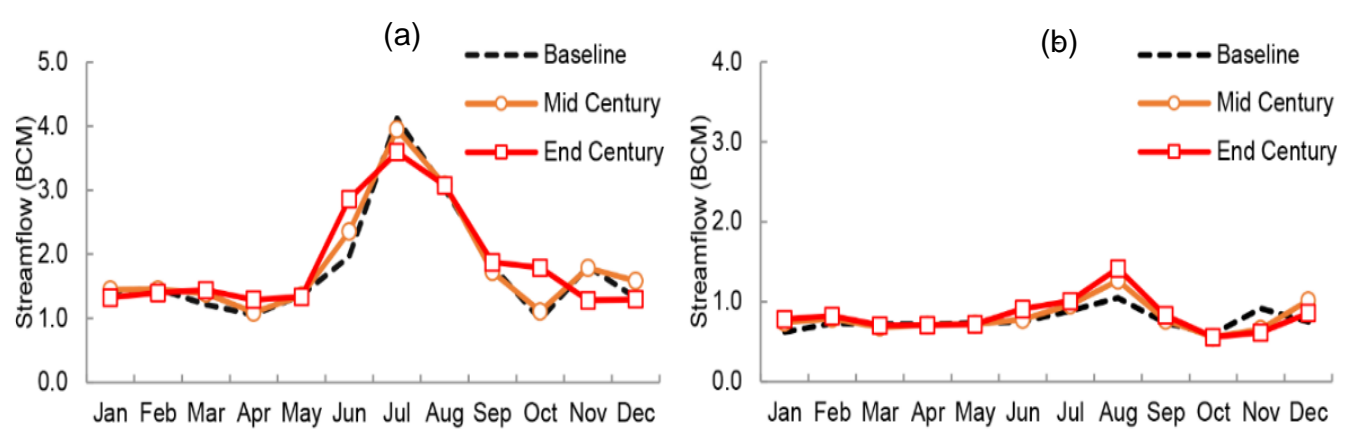

Fig. 7 The projected streamflow for the (a) Sutlej and (b) Beas Rivers during the mid and end century periods 
The runoff in the Sutlej River is much higher than in the Beas River, as stated by NAPCC (2011) that about $25 \%$ of the inflow from the Beas River was diverted to the Sutlej River through a BeasSutlej Link. It was found that, at the end of the century, the flow in the Sutlej River will be slightly different than the mid-century. Furthermore, the glacier melting was also found to contribute to some portion of flow in the Sutlej and Beas Rivers by about 59\% and 35\% of the total runoff, respectively.

Depending on the GCM models, the moderate reduction in irrigation water demand was found at Punjab State by the average of $10 \%$ and Haryana State by $5 \%$ (compared to the baseline). In contrast, the irrigation water demand in Rajasthan State was found to be increased by about $10 \%$ (compared to the baseline) (see Fig. 8 for more details). Interestingly, the abovementioned changes were found to be in line with the changes in land use, which corresponds to in the previous study conducted by (Dau et al., 2021b) using the GFLD-CM3 model under RCP 8.5 scenario and SSP 1 pathway.

(a)
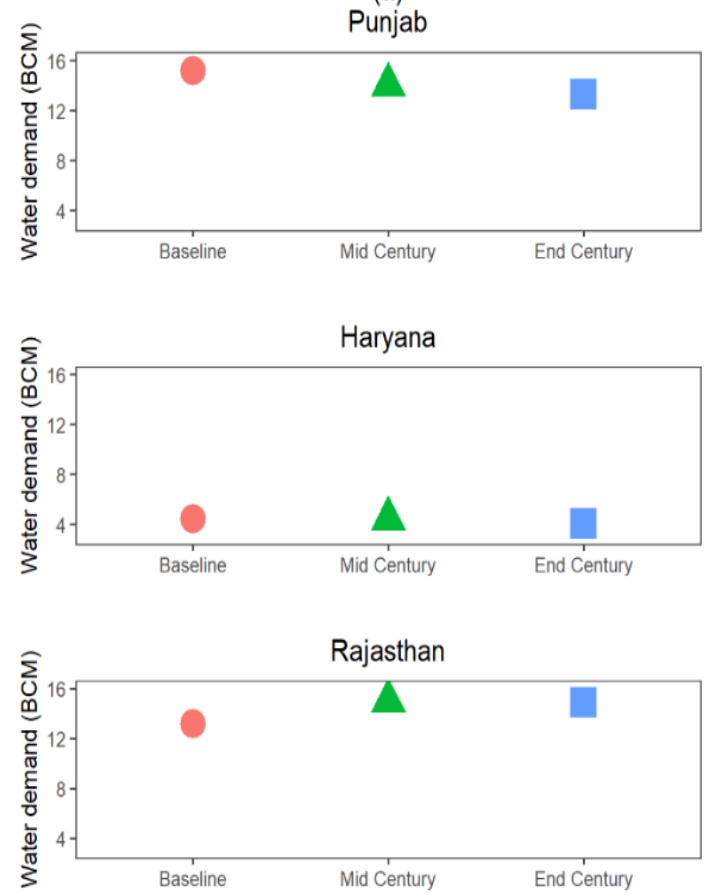

Baseline Mid Century $\square$ End Century (b)

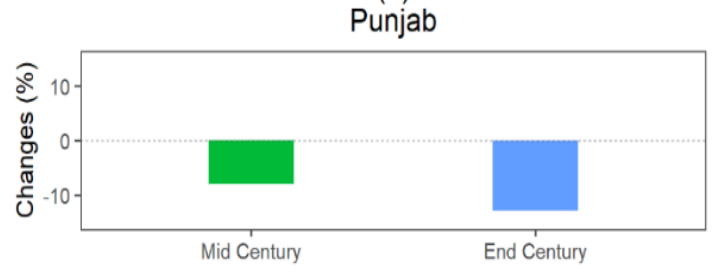

Haryana

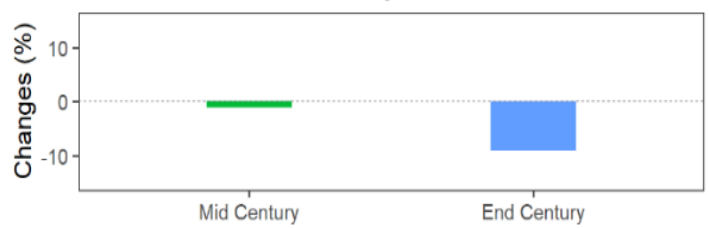

Rajasthan

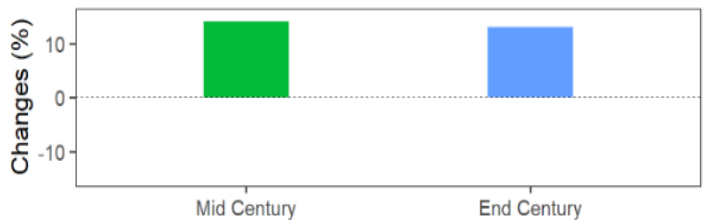

Mid Century | End Century

Fig. 8 The mean irrigation water demand in the cases of (a) annual requirements and (b) changes in the future across the GCM models

Based on the obtained findings from this study, compared to the baseline, the relationship among projected precipitation, projected irrigated command areas, and projected irrigation water demand of each state under future climate and socio-economic conditions is illustrated in simplified Fig. 9 (Note: the figure is not drawn to scale). As seen in Fig. 9a, the states of Punjab, Haryana, and Rajasthan are likely to increase in precipitation, however, the irrigated areas in Punjab and Haryana are expected to decrease and is likely to increase in Rajasthan. In Fig. 9b, it can be noticed that due to the decrease of irrigated areas in Punjab and Haryana, and the increase in Rajasthan, the decrease in irrigation water demand is then clearly seen for both states and is potentially to increase in Rajasthan. 
(a)

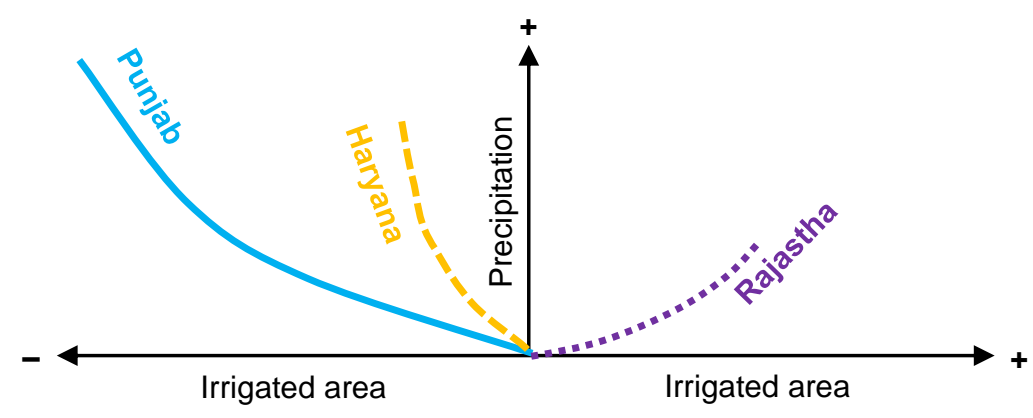

(b)

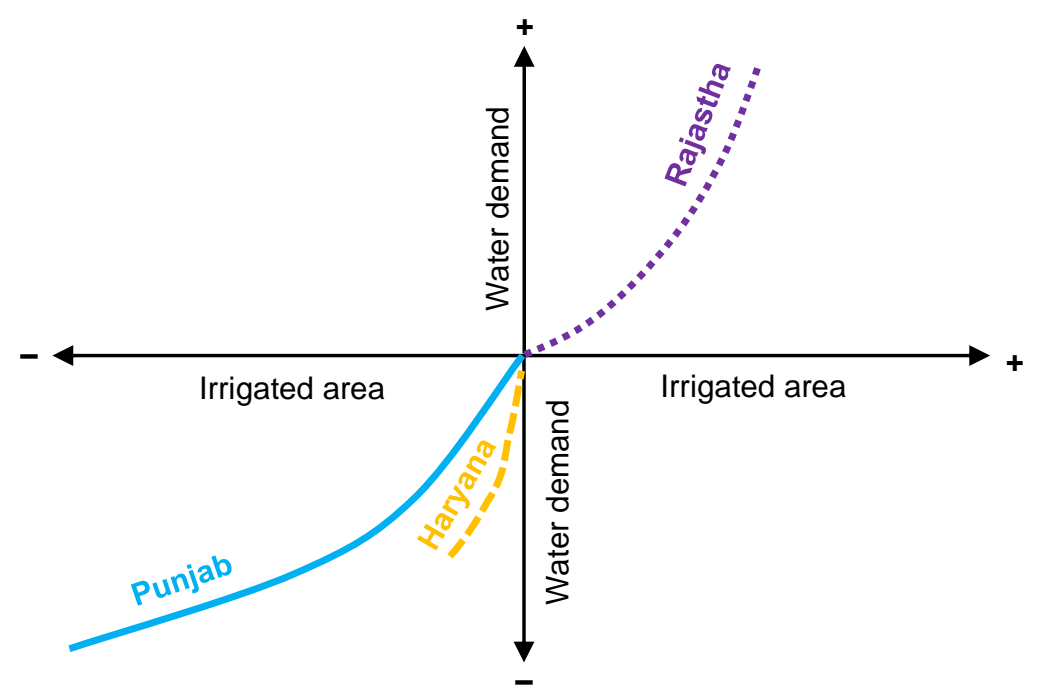

Fig. 9 The relationship between (a) the projected precipitation and the projected irrigated command areas and (b) the projected irrigation water demand and the irrigated command areas of each state under future climate and socio-economic conditions

In line with the population growth under SSP1 scenario, the results expressed a slight shortage for domestic water consumption by $1 \%$ during the mid-century, which is meaningless in comparison to the whole system. Given the increase for future runoff as the consequences of rising in precipitation (5\% to $10 \%$ at the downstream part) and the reduction on irrigation water demand as mentioned previously, efficient water managements such as couple human-natural system, water reuse, or demand-side management, etc. would possibly eliminate water shortage issue for domestic uses. As a conclusion, domestic water consumption will not a huge challenge in this study area.

\section{CONCLUSIONS}

The assessment of the effects of global climate and socio-economic changes on water resources system in the Sutlej-Beas was carried out. The results indicated that future annual precipitation and temperature will increase from baseline, in which high runoffs are likely to occur over the premonsoon to monsoon seasons, as a consequence of glacier melting and heavy rainfall. Based on the land use projections, future irrigated areas in Punjab and Haryana is found to be decreased due to the 
expansion of urban areas, whereas a slight increase is found in Rajasthan. The main findings also suggested that the annual irrigation water demand is expected to increase in Rajasthan State, while it will be decreased in Punjab and Haryana States, as a consequence of climate and land use changes.

The study is certainly not without limitations, some of which are discussed below and will be the purpose of future work. The application of the Delta scaling approach for climate change was justified but it would be better to implement with other methods like the statistical and dynamical downscaling approaches. In addition, relying on only RCP 4.5 and SSP1 scenarios could probably be insufficient to represent all the important aspects of both climate and socio-economic changes. Therefore, applying different RCP and SSP scenarios would minimise the uncertainties in climate model projections.

The outcomes of this study are expected to be beneficial for the Bhakra and Beas Management Board (BBMB) and other relevant agencies in managing the main infrastructures for irrigation water supply, hydropower production, and flood relief, situated in the Beas-Sutlej system.

\section{ACKNOWLEDGEMENTS}

The work reported herein was funded by the UK-NERC (grant numbers NE/N016394/1 and NE/N015541/1) - "Sustaining Himalaya Water Resources in a Changing Climate (SusHi-Wat)" - as part of the UK-India NewtonBhabha Sustainable Water Resources (SWR) thematic Programme.

\section{REFERENCES}

Adeloye, A. J., Wuni, I. Y., Dau, Q. V., Soundharajan, B.-S. \& Kasiviswanathan, K. S. (2019). Height-AreaStorage functional models for evaporation-loss inclusion inreservoir-planning analysis. Water, 11, 1413.

Asoka, A., Gleeson, T., Wada, Y. \& Mishra, V. (2017). Relative contribution of monsoon precipitation and pumping to changes in groundwater storage in India. Nature Geoscience, 10, 109-117.

Bannister, D., Orr, A., Jain, S. K., Holman, I. P., Momblanch, A., Phillips, T., Adeloye, A. J., Snapir, B., Waine, T. W., Hosking, J. S. \& Allen-Sader, C. (2019). Bias correction of high-resolution regional climate model precipitation output gives the best estimates of precipitation in Himalayan catchments. Journal of Geophysical Research: Atmospheres, 124, 14220-14239.

Benestad, R. \& Haugen, J. (2007). On complex extremes: Flood hazards and combined high spring-time precipitation and temperature in Norway. Climatic Change, 85, 381-406.

Censusinfo. (2011). CensusInfo India 2011 - Final population totals [Online]. India. Available: http://dataforall.org/dashboard/censusinfoindia_pca [Accessed May 01 2020].

Chaturvedi, V., Koti, P. N., Sugam, R., Neog, K. \& Hejazi, M. (2020). Cooperation or rivalry? Impact of alternative development pathways on India's long-term electricity generation and associated water demands. Energy, 192, 116708.

Cramér, H. (1946). Mathematical Methods of Statistics (PMS-9), Princeton, Princeton University Press.

Dau, Q. V. \& Adeloye, A. J. (2021). Water security implications of climate and socio-economic stressors for river basin management. Hydrological Sciences Journal.

Dau, Q. V. \& Kuntiyawichai, K. (2020). Identifying adaptive reservoir operation for future climate change scenarios: A case study in Central Vietnam. Water Resources, 47, 189-199.

Dau, Q. V., Kuntiyawichai, K. \& Adeloye, A. J. (2021a). Future changes in water availability due to climate change projections for Huong basin, Vietnam. Environmental Processes, 8, 77-98.

Dau, Q. V., Kuntiyawichai, K. \& Plermkamon, V. (2017). Quantification of flood damage under potential climate change impacts in Central Vietnam. Irrigation and Drainage, 66, 842-853.

Dau, Q. V., Kuntiyawichai, K. \& Suryadi, F. X. (2018). Drought severity assessment in the lower Nam Phong River Basin, Thailand. Songklanakarin J. Sci. Technol., 40, 985-992.

Dau, Q. V., Momblanch, A. \& Adeloye, A. J. (2021b). Adaptation in a Himalayan water resources system under a sustainable socio-economic pathway in a high-emission context. Journal of Hydrologic Engineering, 26. 
Dhawan, V. (2017). Water and Agriculture in India: Background Paper for the South Asia Expert Panel During the Global Forum for Food and Agriculture (GFFA) 2017, OAV - German Asia-Pacific Business Association.

Dong, S., Xu, Y., Zhou, B. \& Shi, Y. (2015). Assessment of indices of temperature extremes simulated by multiple CMIP5 models over China. Advances in Atmospheric Sciences, 32, 1077-1091.

Du, M., Kawashima, S., Yonemura, S., Zhang, X. \& Chen, S. (2004). Mutual influence between human activities and climate change in the Tibetan Plateau during recent years. Global and Planetary Change, 41, 241249.

Fao (2015). FAO AQUASTAT Country profile - India. Italy: Food and Agriculture Organisation of the United Nations.

Gao, J. (2017). Downscaling global spatial population projections from 1/8-degree to 1-km grid cells. NCAR Technical Note NCAR/TN-537+STR.

Goyal, M. K. \& Surampalli, R. Y. (2018). Impact of climate change on water resources in India. Journal of Environmental Engineering, 144, 04018054.

Ires. (2020). India's water resources [Online]. India: Indian Water Resources Society. Available: http://iwrs.org.in/indias-water-resources [Accessed 03 November 2020].

Jain, S., K. Agarwal, P. \& Singh, V. (2007). Hydrology and water resources of India, Springer, Dordrecht.

Krishnan, R., Shrestha, A. B., Ren, G., Rajbhandari, R., Saeed, S., Sanjay, J., Syed, M. A., Vellore, R., Xu, Y., You, Q. \& Ren, Y. (2019). Unravelling climate change in the Hindu Kush Himalaya: rapid warming in the mountains and increasing extremes. In: WESTER, P., MISHRA, A., MUKHERJ, A. \& SHRESTHA, A. B. (eds.) The Hindu Kush Himalaya Assessment: Mountains, Climate Change, Sustainability and People. Cham: Springer International Publishing.

Kulkarni, A. \& Karyakarte, Y. (2014). Observed changes in Himalayan glaciers. Current science, 106, 237 244.

Landis, J. R. \& Koch, G. G. (1977). The measurement of observer agreement for categorical data. Biometrics, 33, 159-174.

Lenderink, G., Buishand, A. \& Van Deursen, W. (2007). Estimates of future discharges of the river Rhine using two scenario methodologies: direct versus delta approach. Hydrol. Earth Syst. Sci., 11, 1145-1159.

Li, H., Xu, C.-Y., Beldring, S., Tallaksen, L. M. \& Jain, S. K. (2016). Water resources under climate change in Himalayan basins. Water Resources Management, 30, 843-859.

Manish, K., Telwala, Y., Nautiyal, D. C. \& Pandit, M. K. (2016). Modelling the impacts of future climate change on plant communities in the Himalaya: a case study from Eastern Himalaya, India. Modeling Earth Systems and Environment, 2, 92.

Marko, K., Zulkarnain, F. \& Kusratmoko, E. (2016). Coupling of Markov chains and cellular automata spatial models to predict land cover changes (case study: upper Ci Leungsi catchment area). IOP Conference Series: Earth and Environmental Science, 47, 012032.

Maurer, J. M., Schaefer, J. M., Rupper, S. \& Corley, A. (2019). Acceleration of ice loss across the Himalayas over the past 40 years. 5, eaav7266.

Meer, M. S. \& Mishra, A. K. (2020). Land Use/Land Cover Changes over a District in Northern India using Remote Sensing and GIS and their Impact on Society and Environment. Journal of the Geological Society of India, 95, 179-182.

Mirza, M. M. Q. \& Ahmad, Q. K. (2005). Climate change and water resources in South Asia, USA, CRC Press.

Moriasi, D. N., Arnold, J. G., Van Liew, M. W., Bingner, R. L., Harmel, R. D. \& Veith, T. L. (2007). Model Evaluation Guidelines for Systematic Quantification of Accuracy in Watershed Simulations. Transactions of the $A S A B E, 50,885-900$.

Mukherji, A., Molden, D., Nepal, S., Rasul, G. \& Wagnon, P. (2015). Himalayan waters at the crossroads: issues and challenges. International Journal of Water Resources Development, 31, 151-160.

Naikoo, M. W., Rihan, M., Ishtiaque, M. \& Shahfahad (2020). Analyses of land use land cover (LULC) change and built-up expansion in the suburb of a metropolitan city: Spatio-temporal analysis of Delhi NCR using landsat datasets. Journal of Urban Management, 9, 347-359.

Napcc (2011). Appendix 2 Lower Sutlej sub-basin. TA 7417- IND: Support for the national action plan on climate change support to the National water mission. India.

Nash, J. E. \& Sutcliffe, J. V. (1970). River flow forecasting through conceptual models part I — A discussion of principles. Journal of Hydrology, 10, 282-290.

Nepal, S. (2016). Impacts of climate change on the hydrological regime of the Koshi river basin in the Himalayan region. Journal of Hydro-environment Research, 10, 76-89. 
O’neill, B. C., Kriegler, E., Riahi, K., Ebi, K. L., Hallegatte, S., Carter, T. R., Mathur, R. \& Van Vuuren, D. P. (2014). A new scenario framework for climate change research: the concept of shared socioeconomic pathways. Climatic Change, 122, 387-400.

Park, Y. S. \& Lek, S. (2016). Chapter 7 - Artificial Neural Networks: multilayer perceptron for ecological modeling. In: JØRGENSEN, S. E. (ed.) Developments in Environmental Modelling. Elsevier.

Pearson, K. (1895). Note on regression and inheritance in the case of two parents. Proceedings of the Royal Society of London Series I.

Penalba, L. M., Elazegui, D. D., Soukkhy, O., Amit, M. G. C., Lansigan, F. P. \& Faderogao, F. J. F. (2014). Climate change impacts on food security and livelihoods: case studies from Lao PDR and the Philippines. In: LEBEL, L., HOANH, C. T., KRITTASUDTHACHEEWA, C. \& DANIEL, R. (eds.) Climate risks, regional integration and sustainability in the Mekong region. Petaling Jaya, Malaysia: Strategic Information and Research Development Centre (SIRDC). Sweden: Stockholm Environment Institute (SEI).

Pontius, R. (2002). Statistical methods to partition effects of quantity and location during comparison of categorical maps at multiple resolutions. Photogrammetric Engineering and Remote Sensing, 68, 1041-1050.

Prasad, V., Kulkarni, A. V., Pradeep, S., Pratibha, S., Tawde, S. A., Shirsat, T., Arya, A. R., Orr, A. \& Bannister, D. (2019). Large losses in glacier area and water availability by the end of the twenty-first century under high emission scenario, Satluj basin, Himalaya. 116, 1721-1730.

Rajbhandari, R., Shrestha, A., Nepal, S. \& Wahid, S. (2018). Projection of future precipitation and temperature change over the transboundary Koshi River basin using Regional Climate Model PRECIS. Atmospheric and Climate Sciences, 8, 163-191.

Samir, K., Marcus, W., Markus, S. \& Wolfgang, L. (2018). Future population and human capital in heterogeneous India. Proceedings of the National Academy of Sciences, 115, 8328-8333.

Sieber, J. \& Purkey, D. (2011). WEAP, water evaluation and planning system. U.S. Center, Somerville, USA: Stockholm Environment Institute.

Siebert, S., Burke, J., Faures, J. M., Frenken, K., Hoogeveen, J., Döll, P. \& Portmann, F. T. (2010). Groundwater use for irrigation - a global inventory. Hydrol. Earth Syst. Sci., 14, 1863-1880.

Singh, P. \& Bengtsson, L. (2004). Hydrological sensitivity of a large Himalayan basin to climate change. Hydrol. Process., 18, 2363-2385.

Taylor, K. E., Stouffer, R. J. \& Meehl, G. A. (2012). An overview of CMIP5 and the experiment design. Bulletin of the American Meteorological Society, 93, 485-498.

Tebaldi, C. \& Knutti, R. (2007). The use of the multi-model ensemble in probabilistic climate projections. Phil. Trans. R. Soc. A., 365, 2053-2075.

Wang, B., Zheng, L., Liu, D. L., Ji, F., Clark, A. \& Yu, Q. (2018). Using multi-model ensembles of CMIP5 global climate models to reproduce observed monthly rainfall and temperature with machine learning methods in Australia. International Journal of Climatology, 38, 4891-4902.

Yates, D., Purkey, D., Sieber, J., Huber-Lee, A. \& Galbraith, H. (2005). WEAP21-A demand-, priority-, and preference-driven water planning model. Water International, 30, 501-512. 